\title{
Research on the Relationship between Assets Impairment and Debt Financing Costs
}

\author{
Xixi Zhang ${ }^{\mathrm{a}, *}$, Yuan Su${ }^{\mathrm{b}}$ \\ School of Economics and Management, Nanjing University of Science and Technology, Nanjing \\ 210094, China \\ a771682547@qq.com, ${ }^{b}$ 632895189@qq.com
}

Keywords: Assets impairment; Debt financing costs; Timeliness.

Abstract: Financing is an important business decision for an enterprise, while debt financing costs is a key indicator for corporate financing decisions. The paper uses a sample of the manufacturing companies spanning the period 2012-2016 to study whether the company's assets impairment will affect the cost of debt financing. The more the company's assets impairment losses, the higher debt financing costs, and the more asset depreciation reserves the company can reverse, the higher the debt financing costs. Further research shows that the impact of assets impairment on the cost of debt financing will continue to the second year.

\section{Introduction}

Enterprises are facing great uncertainty and risks in an ever-changing environment. In order to effectively prevent risks and reduce the risk losses that may arise from business operations, the “Accounting System for Business Enterprises" stipulates that companies should conduct comprehensive inspections of all assets on a regular basis or at least at the end of each year, reasonably predict the possible losses of various assets, and make provision for impairment of assets for all asset losses that may occur.

Debt financing can ensure the capital needs of the company, obtain financial leverage. Debt financing costs reflect the degree of difficulty in financing. Therefore, reducing the cost of debt is an important factor for companies to consider. Due to the manipulability of assets impairment, companies often choose to use assets impairments for earnings manipulation, which will cause the noise and bias of the accounting information disclosed by the company, thus it may affect the decisions of external creditors. Based on the above analysis, this paper examines the relationship between assets impairment and debt financing costs.

\section{Related literature and hypothesis development}

At present, most of the literature states that assets impairment is a means for companies to manage earnings, but very few studies have examined the economic consequences of assets impairment. 
Regarding the cost of debt financing, scholars have mainly studied the influence factors, including external and internal factors. The external factors include government intervention, degree of marketization, and bank affiliation. The internal factors include accounting information quality, internal control quality and earnings management. This article will analyzes whether the asset impairment information will affect the company's debt financing costs.

In a comprehensive view, the accrual and the reversal of impairment provisions are intended to truly reflect the value of assets, and improve the reliability of accounting information. However, it is because companies cannot accurately estimate the value of assets, which leads managers to manage accounting earnings. As a result, there are uncertainty in financial reporting, which increases information risk. This source of information risk may be included in the debt contract because if the creditor perceives that the assets impairment reserve is a performance of earnings management, additional monitoring measures may be taken and a higher risk premium may be required. Therefore, we state our first hypothesis as follows.

H1: The more impairment loss of listed company assets, the higher the cost of debt financing.

The 2006 Accounting Standards for Business Enterprises Standard No. 8 stipulates that once a listed company's assets impairment loss for long-term assets is recognized, it cannot be reversed in subsequent accounting periods, but there are no relevant regulations for current assets. Therefore, companies are more likely to make withdrawals and reversals of current assets for earnings management, thereby increasing the information risk of financial reporting and increasing the cost of debt financing. This discussion leads to our second hypothesis.

H2: The more asset depreciation reserves a listed company can reverse, the higher its debt financing costs.

\section{Research design and sample selection}

\subsection{Sample selection and data sources}

This paper selects manufacturing companies listed on the Shanghai and Shenzhen A-Shares from 2012 to 2016 as samples. Considering that the impact of assets impairment on corporate debt financing costs has lagged effects and eliminates endogenous effects, this paper lags the cost of debt financing by one period and uses the next period of interest payment. We finally receive 2157 observations.

\subsection{Definition of variables}

The dependent variable, Debtcosts, is the cash paid for repayment of interest to account for the total amount of the final borrowings. The two independent variables are Limpair and Simpair, which are the ratio of assets impairment loss to total assets to test hypothesis 1 , and the ratio of reversed impairment provision to total assets to test Hypothesis 2.

We also choose control variables that are important to the cost of debt financing. We select Size, the natural log of total assets. Current is Current assets divided by current liabilities. Lev is total liabilities divided by total assets. Turnover is main business income divided by average total assets. $R O A$ is net profit divided by average balance of total assets. Assetgro is the difference between the total assets at the end of the period and the total assets at the beginning of the period divided by total assets at the beginning. $J R$ is one if the chairman and general manager are the same person, otherwise take zero. Indboard is the proportion of independent directors. $D R$ is the sum of the shareholding ratio of the second to tenth largest shareholders divided by the shareholding ratio of the largest shareholder. 
Mshare is executives holding shares divided by total number of shares. Opinion is one if annual report is issued with clean opinion, otherwise 0 . Loss is one if the company's net profit for the year is less than 0 , otherwise take 0 . State is one if company is state-owned, otherwise takes 0 .

\subsection{Model design}

This paper establishes the following analysis model.

Debtcost $=\beta_{0}+\beta_{1}$ Limpair $+\beta_{2}$ Size $+\beta_{3}$ Current $+\beta_{4}$ Lev $+\beta_{5}$ Turnover $+\beta_{6}$ ROA $+\beta_{7}$ Assetgro $+\beta_{8} J R$ $+\beta_{9}$ Indboard $+\beta_{10}$ DR $+\beta_{11}$ Mshare $+\beta_{12}$ Opinion $+\beta_{13}$ Loss $+\beta_{14}$ State $+\varepsilon$ (1)

Debtcost $=\beta_{0}+\beta_{1}$ Simpair $+\beta_{2}$ Size $+\beta_{3}$ Current $+\beta_{4}$ Lev $+\beta_{5}$ Turnover $+\beta_{6}$ ROA $+\beta_{7}$ Assetgro $+\beta_{8} J R$ $+\beta_{9}$ Indboard $+\beta_{10} D R+\beta_{11}$ Mshare $+\beta_{12}$ Opinion $+\beta_{13}$ Loss $+\beta_{14}$ State $+\varepsilon$ (2)

\section{Empirical results}

\subsection{Descriptive statistical analysis}

From descriptive statistical analysis, the average Debtcost cost is 0.3445 , and the standard deviation is 1.0391. This shows that the debt financing costs of different companies are quite different. The two independent variables indicate that there is a large difference in the amount of assets impairment between companies.

\subsection{Correlation analysis}

The coefficient between Debtcost and Limpair is -0.04 , it is significant at the level of $10 \%$, which means that the assets impairment loss and the debt financing costs are significant negative correlation. The coefficient between Debtcost and Simpair is -0.048, it is significant at the level of $10 \%$. In addition, the maximum correlation between variables is 0.621 , there is no multicollinearity problem between the variables.

\subsection{Regression analysis}

Columns (1) and (2) of Table 1 respectively show multiple regression analysis of Model 1 and Model 2.

Column (1) reports the regression results of model (1), the coefficient between Limpair and Debtcost is 6.146, which is significant positive correlation at the $1 \%$ level. It is formally test hypothesis 1. Column (2) shows the results of Model 2. It shows that the coefficient between Debtcost and Simpair is positive and significant at the level of $10 \%$, the result supports Hypothesis 2 .

Consider whether the impact of assets impairment recorded in Table 1 on the cost of debt financing will continue to the second and third years, that is, whether this effect will exceed one year. We select the cost of debt financing for the year $t+2$ and the year $t+3$, respectively, and retests Model 1 and Model 2. The results show that the impact of assets impairment on the cost of debt financing will continue until the second year, but the impact will be lessened. The third year of influence has disappeared. 
Table 1 Result of Model 1and Model 2

\begin{tabular}{|c|c|c|c|c|}
\hline \multirow{3}{*}{ Variable } & \multicolumn{4}{|c|}{ Dependent Variable } \\
\hline & \multicolumn{2}{|c|}{ (1)Debtcost } & \multicolumn{2}{|c|}{ (2)Debtcost } \\
\hline & $\mathrm{B}$ & Sig. & $\mathrm{B}$ & Sig. \\
\hline & -1.629 & .000 & -1.703 & .002 \\
\hline Limpair & 6.146 & .000 & -- & -- \\
\hline Simpair & -- & -- & .292 & .087 \\
\hline Size & .098 & .000 & .105 & .000 \\
\hline Current & .097 & .000 & .097 & .000 \\
\hline Lev & .567 & .000 & .648 & .000 \\
\hline Turnover & .106 & .016 & .122 & .006 \\
\hline ROA & 4.784 & .000 & 3.713 & .000 \\
\hline Assetgrow & -.055 & .306 & -.070 & .196 \\
\hline JR & -.076 & .160 & -.078 & .155 \\
\hline Indboard & -.288 & .464 & -.321 & .417 \\
\hline DR & -.083 & .006 & -.075 & .015 \\
\hline Mshare & -.698 & .168 & -.653 & .200 \\
\hline Opinion & -.160 & .106 & -.147 & .140 \\
\hline Loss & .244 & .001 & .262 & .000 \\
\hline State & -.044 & .325 & -.054 & .235 \\
\hline Adj. $-\mathrm{R}^{2}$ & \multicolumn{2}{|c|}{.125} & \multicolumn{2}{|c|}{.114} \\
\hline Obs. & \multicolumn{2}{|c|}{2157} & \multicolumn{2}{|c|}{2157} \\
\hline
\end{tabular}

\section{Conclusions}

This article shows that companies which are inclined to use assets impairment losses and asset that can be reversed have higher debt financing costs. This article discusses the economic consequences of the company's earnings management from the perspective of assets impairment, it enriches the literature on debt financing costs. This article may make some suggestions for the results. First, company should strengthen the management of asset to prevent the information risk caused by improper handling of assets impairment losses, otherwise it will increase the debt cost of the enterprise. Then, Investors should not only pay attention to the company's key financial indicators, but also comprehensively analyze the disclosed financial information.

\section{References}

[1] Chen, K.C.W., and H .Yuan, Earnings Management and Capital Resource Allocation: Evidence from China's Accounting-Based Regulation of Rights Issues, The Accounting Review, 2004.

[2] Haw, I., D.Qi, D.W u, and W.W u, Market Consequences of Earnings Management in Response to Security Regulations in China, Contemporary Accounting Research, 2005.

[3] Lambert, R, Luze. Accounting Information, Disclosure, and the Cost of Capital [J].Journal of Accounting Research, 2007(45):385-420.

[4] Dechow, P., W .Ge, and C.Schrand, Understanding Earnings Quality: A Review of the Proxies, their Determinants and their Consequences, Journal of Accounting and Economics, 2010.

[5] Hatem Ghouma. How does managerial opportunism affect the cost of debt financing? [J]. Research in International Business and Finance, 2017, 39.

[6] Zhao Chunguang. Impairment of Assets and Earnings Management: On the Policy Implication of the "Assets Impairment" Criterion [J]. Accounting Research, 2006 (03): 11-17+96. 